\title{
What to Expect from Basel III?
}

Dear readers,

I would like to dedicate the third edition of European Financial and Accounting Journal to contemplate what could be anticipated from Basel III. The development and global impact of financial crisis have been so intense that it could not remain without politic and regulatory response. Thus the officials come up with the new proposals for more strict regulations that would prevent the financial crisis of comparable size from recurring.

What changes will the enforcement of Basel III bring to the banks and what might be expected from them? In short, the equity capital should increase and its quality should improve. This should become evident in a greater stability of the financial system.

The increase in minimum capital (strictly speaking, the global minimum capital standards) will be required from banks in two basic ways. The first lies in implementation of a conservation buffer at $2.5 \%$ above the regulatory minimum, which should be instrumental to absorb additional bank losses when the economy does not flourish and banks would make greater losses consequently. Banks shall not have automatically the obligation to create this kind of capital, nevertheless if they fail to obey, they will be subjected to explicit restrictions on paying dividends to shareholders and bonuses to the managers. Banks will more likely to avoid such situation, thus it could be expected, that they will implement the capital increase voluntarily.

The second form is countercyclical capital buffer, which should reduce criticized weakness of the current Basel II, namely its rather pro-cyclical nature. The application of this buffer will be in competence of national regulators, who shall be able to increase the capital ratio by 2.5 percent if the volume of credits in economy grows faster than GDP. The capital increase should take place in the banks in advance in the time economy growth and on the contrary in recession this generated capital will be used for to cover losses.

The capital increase is mostly considered necessary because the current capital buffer has turned up to be entirely insufficient. On the 
other hand it should be noted that the planned capital increase cannot ensure the survival of all banks during the another financial crisis because the decline in assets values may of course be higher than the banks would be capable to absorb even from increased capital. The significant role will be played also by the assets valuation because banks could reach a new required level of capital ratio through a capital increase but also by reducing risk-weighted assets. The valuation and taking into account the risks involved is of a crucial importance for their determination.

In addition to the quantitative increase in capital Basel III puts more emphasis on its qualitative composition. This is reflected in the fact that the global minimum capital standards ratio based on common equity capital increases. Thus banks will have to obtain new capital required also by an expansion of the authorized capital. In a theoretical point of view it should contribute to increase commitment of shareholders to bank functioning of banks. The practical impact is questionable in this respect, since the financial crisis has shown us that the liability of shareholders in a number of large banks in particular did not work. The banks under the prospect of higher appreciation often launched themselves into relatively high-risk operations that endangered the very existence of the banks (and in some cases led to their downfall), and the shareholders did not prevent them from doing so. The whole problem is not that simple as it seems to us today. It should be noted that what is clear to everyone now, before the crisis it appeared very differently. Sophisticated methods of risk measurement, an objective rating valuations, elaborated regulation - these are just some characteristics that no one questioned too much before the crisis and which given a rise to rather positive expectations in their way. It is difficult to blame shareholders now that they did not identify the high risks in that time. The problem is not that simple as it seems to be. Based on this experience it is therefore not possible to assume that higher impact on shareholders in consequence of higher proportion of authorized capital in the banks shall bring from their part significant pressure to reduce the risk undergone by these banks. Maybe it would work for currently known instruments and associated risks but the development cannot stopped and there new instruments may bring new problems.

So what can be expected from the new rules? For sure it shall bring the higher ability of banks to cope with potential losses due to more capital reserves. On the other hand, we have already learned enough from the history that absolutely no regulation ensure to provide fully stable system and it is doubly true about the financial system. Therefore, at the 
end it shall be decisive from the behavior of all entities resulting from their inside motivation. And as their behavior will never be adequately guarded at all nor regulation can fully enforce such a caution. It can only regulate it in a certain way.

Basel III shall stand in good stead to financial system but what shall be its real implications and to what extent shall the aims be fulfilled which its creators input into it, or, conversely, how considerably banks shall seek to find (open up possibilities) and apply by which they shall endeavour to avoid new rules. This shall be possible to evaluate in the horizon of 10-15 years. A timetable for Basel III implementation is allocated till 2019.

doc. Ing. Petr Dvořák, Ph.D.

dean of Faculty of Finance and Accounting,

University of Economics, Prague 